\title{
Pengaruh Kemampuan dan Motivasi Dosen \\ terhadap Kualitas Layanan kepada Mahasiswa STAI Darul UlumBanyuwangi
}

\section{Supriyanto}

Sekolah Tinggi Agama Islam Darul Ulum Banyuwangi

\section{Abstract:}

One of the efforts to make our higher education institutions to be in the same level with those of other nations is by improving the quality of the lecturers and their service to students. The research was conducted at the STAI Darul Ulum Banyuwangi, with a population of 132 people and 64 people of sample. The method of data collection is by using questionnaires and the method of data analysis is by using the analysis of double regression predictors. The results of this research show that: firstly, the lecturers' abilities significantly influence the quality of services to students. Secondly, the lecturers' teaching motivation also significantly influence the quality of services to students. Thirdly, the lecturers' abilities are related to their teaching motivations. Finally the lecturers' abilities and the teaching motivation simultaneously influence the quality of service to students.

Keywords: quantitative design, ability, motivation, and service. 


\section{Abstrak:}

Salah satu usaha untuk menjadikan pendidikan tinggi kita sejajar dengan bangsa lain, diperlukan perbaikan terutama pada perbaikan mutu dosen dan kualitas layanan kepada mahasiswa. Penelitian ini dilakukan di STAI Darul Ulum Banyuwangi, dengan populasi 132 orang dan sampel 64 orang. Metode pengumpulan data menggunakan metode angket dan analisis data menggunakan analisis regresi ganda dua predictor.

Hasil penelitian ini menunjukan bahwa; pertama, kemampuan dosen berpengaruh secara signifikan terhadap kualitas layanan kepadamahasiswa;kedua, motivasimengajardosenberpengaruh secara signifikan terhadap kualitas layanan kepada mahasiswa; ketiga, kemampuan dosen berhubungan dengan motivasi mengajar; dan keempat, kemampuan dan motivasi mengajar dosen secara simultan berpengaruh signifikan terhadap kualitas layanan kepada mahasiswa.

Kata Kunci: kuantitatif design, kemampuan, motivasi, layanan. 


\section{A. PENDAHULUAN}

$\mathrm{P}$ endidikan diyakini oleh banyak bangsa di dunia sebagai satu-satunya jalan untuk keluar dari keterbelakangan, kemiskinan dan kebodohan. Pendidikan juga sudah terbukti dapat berkontribusi pada upaya memajukan ilmu pengetahuan dan teknologi di hampir semua negara di dunia. Bangsa-bangsa yang telah maju ilmu pengetahuan dan teknologinya, adalah bangsa yang telah bersusah payah membangun fondasi yang kokoh bagi kelangsungan pendidikannya, seperti Singapura, Jepang, Iran, Jerman, Inggris, Amerika Serikat, dan Australia.

Pendidikan juga diyakini menjadi satu-satunya jalan untuk memutus mata rantai kemiskinan. Istilah lingkaran setan dalam kemiskinan, adalah kondisi dimana orang akan sulit keluar dari kemiskinan yang menjeratnya. Para ahli meyakini bahwa, dengan pendidikan orang diberikan pengetahuan, keterampilan dan bahkan keahlian, sehingga dengan bekal pengetahuan, keterampilan dan keahlian itu, orang akan dapat menolong dirinya sendiri untuk keluar dari lingkaran setan kemiskinan. Selanjutnya secara simultan, orang yang sudah terbebas dari kemiskinan dapat menolong oranglain, sepertikeluarga dan orang-orang dekatnya.

Salah satu penyebab kemiskinan adalah kebodohan. Orang yang bodoh tidak memiliki kemampuan dan posisi tawar yang cukup untuk memasarkan kemampuanya dalam dunia kerja. Mereka selalu kalah dalam persaingan kehidupan, karena itu mereka tidak dapat mengakses sumber-sumber ekonomi sehingga menjadi miskin. Pendidikan diyakini dapat memberikan bekal pengetahuan, keterampilan, keahlian dan akses informasi bagi semua orang untuk dapat bersaing maupun bekerjasama dalam kehidupan nyata. Mereka yang berpendidikan dapat bersaing di dunia kerja untuk mendapatkan penghasilan bagi kebutuhanya. Mereka yang berpendidikan memiliki akses untuk dapat bekerja sama dalam berbagai bidang bisnis dan usaha meningkatkan kemampuan mengajar. Singkat kata, pendidikan yang dimiliki akan dapat menolonghidupnya. 
Usaha untuk memajukan dunia pendidikan telah dilakukan oleh pemerintah sejakrepublikini berdiri, sehinggalebih darisetengah abad pendidikan kita dibangun. Namun, jika dibanding dengan bangsa-bangsa lainya, kita patut untuk instrospeksi dan kemudian memperbaiki mutu pendidikan kita, khususnya pendidikan tinggi kita. Berdasarkan berbagai survey yang dilakukan oleh lembaga survey internasional, posisi perguruan tinggi kita belum ada yang masuk sepuluh besar perguruan tinnggi dunia, bahkan seratus besar pun belum. Ini tentu kalah dengan China, Jepang, Korea, dan Singapura yang perguruan tingginya masuk seratus besar dunia. Jepang misalnya, 6 perguruan tingginya masuk ke dalam 100 besar dunia, disusul Hongkong yang 3 perguruan tinggi dan Korea Selatan dan China ada 2 perguruan tingginya masukjuga seratus besar. Meskipun berada di Asia Tenggara, ternyata Singapura juga masuk peringkat seratus besar, sedangkan perguruan tinggi Indonesia harus puas diperingkat 201 dunia, yakni Universitas Indonesia. Berdasarkan beberapa hasil survey tersebut, rangking perguruan tinggi kita masih ke dalam urutan dua ratusan, bahkan sebagian besar berada pada periangkat seribu besar, bahkan perguruan tinggi perintis masih adayang berada diatas tiga ribu. Bandingkan dengan beberapa perguruan tinggi negeri tetangga kita seperti; Singapura, Hongkong Jepang, dan Korea. Ini menjadi realitas yang menantang kita semua untuk meningkatkan mutu dan pelayanan pada pendidikan tinggi kita. Karena hanya dengan meningkatkan mutu penelitian, pendidikan dan kegiatan layanan pengembangan illmu lah, pendidikan tinggi dapat ditingkatkan sesuai dengan amanat tri dharma perguruan tinggi.

Faktorpentingyangdapatmeningkatkanmutupendidikantinggi kita adalah layanan dosen dan pengelola perguruan tinggi kepada mahasiswa. Mahasiswa diyakini menjadi variable penting yang harus ditingkatkan guna meningkatkan mutu pendidikan tinggi. Karena itu faktor mahasiswa menjadi salah satu faktor kunci. Untuk meningkatkan layanan kepada mahasiswa diperlukan kemampuan dan motivasi mengajar dosen. Kemampuan dosen bukan hanya kemampuan akademis, tetapi juga kemampuan pendukung 
lainya yang diperlukan untuk meningkatkan manajemen layanan kampus kepada para mahasiswa. Dosen yang memiliki kemampuan yang baik diharapkan dapat meningkatkan motivasi belajar bagi mahasiswa. Sebab berbagai hasil studi menunjukan bahwa, kemampuan mengajar, kemampuan membimbing, kemampuan menjaditrainerdan mentordaridosen, sangatberpengaruh positif terhadap keberhasilan belajar mahasiswa, terutama perguruan tinggi yang ingin meningkatkan statusnya menjadi perguruan tinggi bertarafdunia.

Survey terdadap perguruan taraf dunia mendasarkan pada 6 indikator. Yakni publikasi atas hasil penelitian, animo mahasiswa internasional, rasio dosen dengan mahasiswa, hasil penelitian pada tiap bidang ilmu, program pendidikan internasional, dan jumlah mahasiswa internasional ${ }^{1}$.

Berdasarkan indikator kinerja perguruan tinggi top dunia tersebut diatas, maka dapat diketahui bahwa setiap perguruan tinggiyangakan menjadi word class university harus membangun indikator-indikator tersebut. Untuk dapat mencapai indikator tersebut, diperlukan sumberdaya manusia yang berkualitas. Kualitas sumberdaya manusia dapat meningkat jika kemampuan juga meningkat. Kemampuan akan meningkat kalau motivasinya meningkat, karena itu kemampuan dan motivasi mengajar segenap civitas akademika sangatlah penting bagi perguruan tinggi yang akan meningkatkan diri.

Motivasi mengajar juga diyakini memiliki potensi pengaruh positif bagi dosen untuk melayani mahasiswa. Motivasiyang kuat untuk melayani mahasiswa, tidak hanya berdampak pada hubungan antara dosen dan mahasiswa dalam bidang akademik, tetapi secara psikologis akan berpengaruh terhadap minat, perhatian, persepsi, bahkan karakter mahasiswa setelah keluar dari bangku kuliah. Mahasiswa yang dilayani dengan baik oleh dosenya, akan cenderung memiliki perhatian dan motivasi yang baik jika kelak melayani orang lain sehubungan dengan tugasnya.

${ }^{1}$ The QS Words University Rangkings. Quacquarelly Symonds. 2009. Publikasi oleh http: www. ruanghati. com. Desember. 2010. Dapat diakses juga di http://i684. photobucket. com/albums /vv210/mesinkasir/metode.png. 
Kemampuan dan motivasi dosen juga diharapkan akan memacu perguruan tinggi untuk meningkatkan kinerjanya dalam melaksanakan amanat tridharma perguruan tinggi, yakni pendidikan dan pengajaran, penelitian dan pengabdian pada masyarakat. Jika dosen memiliki kemampuan dan motivasi tertentu, diharapkan akan dapat berkontribusi pada peningkatan kinerja perguruan tinggi, termasuk layanan pendidikan kepada para mahasiswa. Melalui penelitian ini diharapkan akan dapat diketahui sejauhmana pengaruh kemampuan dosen dan motivasi mengajar dosen terhadap layanan pendidikan kepada mahasiswa.

Berdasarkan batasan masalah tersebut diatas maka masalah dalam penelitian ini dirumuskan sebagai berikut: (1) Sejauhmanakah pengaruh kemampuan terhadap kualitas layanan dosen kepada mahasiswa? (2) Sejauhmanakah pengaruh motivasi mengajar dosen terhadap kualitas layanan kepada mahasiswa? (3) Sejauhmanakah pengaruh kemampuan terhadap motivasi mengajar? (4) Sejauhmanakah pengaruh kemampuan dan motivasi mengajar secara simultan terhadap kualitas layanan kepada mahasiswa?

\section{B. KAJIAN TEORITIK}

1. Pengaruh Kemampuan Dosen Terhadap Layanan Pendidikan.

Sutermeister ${ }^{2}$ mengatakan bahwa: kemampuan adalah faktor penting dalam meningkatkan produktivitas kerja, kemampuan berhubungan dengan pengetahuan (Knowledge) dan keterampilan (Skill) yang dimiliki seseorang. Selanjutnya Bob Davis et.al ${ }^{3}$ mengatakan bahwa keterampilan dan kemampuan adalah dua hal yang saling berhubungan dimana kemampuan seseorang dapat dilihat dari keterampilan yang diwujudkan melalui tindakannya. Kemampuan yang didasari oleh kreativitas dan keterampilan adalah proses mental, yang diarahkan untuk mencapai tujuan tertentu.

\footnotetext{
${ }^{2}$ Sutermeister. People and Productivity (Third Edition), (New York: Mc. Grow Hill Book Company, 1976), h. 1.

${ }^{3}$ Bob Davis, Et.al, Physical Education and The Study of Sport, (Second Edition), (Mosby: Times Mirror International Publisher Limited, 1994)
} 
2. Pengaruh Motivasi Mengajar Dosen Terhadap Layanan Pendidikan

Dosen dalam menjalankan tugas dan fungsinya dalam layanan pendidikan harus dilandasi oleh kesadaran akan tugas, tanggungjawab, dan keinginanyang tinggiagar tugas melayani mahasiswa dapat terselenggara dengan baik dan memuaskan. Oleh karena itu, setiap kepala perguruan tinggi hendaknya memperhatikan kebutuhan dosen sebagaimana diuraikan dalam teori motivasi. Kebutuhan utama para dosen harus diperhatikan yang meliputi antara lain: kebutuhan fisik dan kebutuhan jaminan bekerja. Pemenuhan kebutuhan fisik yang wajar dapat diharapkan dosen akan melaksanakan tugas kependidikan secara baik dan sungguh-sungguh.

\section{Hipotesis Penelitian}

Hipotesis yang diajukan dalam penelitian adalah sebagai berikut :

a. Ada pengaruh yang signifikan antara kemampuan dosen terhadap layananan pendidikan di STAI Darul Ulum Banyuwangi.

b. Ada pengaruh yang signifikan antara motivasi mengajar dosen terhadap layananan pendidikan di STAI Darul Ulum Banyuwangi.

c. Ada pengaruh yang signifikan antara kemampuan dengan motivasi mengajar dosen diSTAI Darul Ulum Banyuwangi.

d. Ada pengaruh yang signifikan antara kemampuan dan motivasi mengajar dosen secara simultan terhadap layananan pendidikan STAI Darul Ulum Banyuwangi.

\section{METODE PENELITIAN}

1. Jenis Penelitian

Penelitian ini menggunakan variasi metode korelasional dengan maksud untuk mengungkapkan korelasi antara variabel 
yang dilibatkan dalam penelitian dan supaya mendapatkan informasi yang lengkap mengenai kaitan diantara variabelvariabel yang diteliti. Sesuai dengan tujuan penelitian dan rumusan masalah penelitian yang telah ditetapkan maka rancangan penelitian ini termasuk penelitian korelasional, karena menguji dan mengungkapkan pengaruh antara variabel bebas dengan variabel terikat. Dan jika dilihat dari cara pengumpulan data, penelitian ini termasuk ex post facto. Menurut Nana Sudjana dan Ibrahim (1986:56) rancangan penelitian ex-post facto adalah rancangan penelitian yang menunjukan kepada perlakuan atau manipulasi variable bebas (X)yang telah terjadi sebelumnya sehingga peneliti tidak perlu memberikan perlakuan lagi, tinggal melihat efeknya terhadap variable terikat. Penelitian korelasional atau Correlational Research bertujuan untuk mendeteksi seberapa jauh variasivariasi pada suatu faktor berkaitan dengan variasi-variasi pada satu atau lebih faktor lain berdasarkan pada koefisien variasi (Suryabrata, 1983: 24). Penelitian ini dimaksudkan untuk mengungkap berapa besar hubungan secara sendiri-sendiri atau secara bersama-sama antara kemampuan guru terhadap penerapan model pembelajaran kontekstual dan antara motivasi mengajar guru terhadap kualitas layanan kepada mahasiswa serta pengaruh secara bersama antara kemampuan guru dan motivasi mengajar guru terhadap penerapan model pembelajaran kontekstual.

\section{Tempat dan Waktu Penelitian}

Penelitian ini dilakukan di Sekolah Tinggi Agama Islam Darul Ulum, Jalan KH Askandar No: 9 Wringinputih Muncar Kabupaten Banyuwangi Propinsi Jawa Timur. Penelitian dilaksanakan mulai tanggal 12 sampai 24 Desember 2010.

3. Populasi, Sampel dan Teknik Sampling

a. Populasi

Populasi sasaran dalam penelitian ini adalah semua dosen di STAI Darul Ulum Banyuwangi yang mempunyai masa kerja di atas tiga tahun sebanyak 132 orang dosen. 
b. Teknik Pengambilan Sampel

Sejalandenganpermasalahanyangditelitidalampenelitian ini, yaitu pengaruh kemampuan dan motivasi mengajar dosen terhadap layanan kepada mahasiswa sehingga, untuk menghindari adanya distorsi hasil penelitian, pengambilan sampel akan dikerjakan memakai teknik Random Sampling. Dalam penelitian inijumlah anggota populasi sebanyak 132 orang dosen dan populasi diambil 64 dosen.

\section{Metode Pengumpulan Data}

Alat ukur penelitian ini berbentuk angket, dengan tingkat pengukuran ordinal, kategorijawaban terdiri atas 5 tingkatan. Untuk analisis secara kwantitatif, maka alternatif jawaban tersebut dapat diberi skor dan nilai 1 sampai 5 sebagai berikut.

a. Adalimaalternatifjawaban untukvariabel kemampuan dan motivasi mengajar, yaitu :

$$
\begin{aligned}
& 5=\text { Selalu atau Sangat Tinggi } \\
& 4=\text { Sering atau Tinggi } \\
& 3=\text { Kadang-kadang atau Cukup Tinggi } \\
& 2=\text { Jarang atau Rendah } \\
& 1=\text { TidakPernah atau Rendah Sekali }
\end{aligned}
$$

b. Penskoran Penerapan model pembelajaran kontekstual

\begin{tabular}{|c|l|c|}
\hline No & \multicolumn{1}{|c|}{ Kategori Jawaban } & Skor \\
\hline 1. & Sangat Setuju & 5 \\
2. & Setuju & 4 \\
3. & Ragu - ragu & 3 \\
4. & Tidak Setuju & 2 \\
5. & Sangat Tidak Setuju & 1 \\
\hline
\end{tabular}

\section{Instrumen Penelitian}

Instumen penelitian ini berbentuk angket yang disebarkan kepada 64 Dosen di STAI Darul Ulum. Untuk membuat angket tersebut, terlebih dulu dibuat kisi-kisi yang menjadi garis 
besar pembuatan angket. Kisi-kisi instrumen penelitian ini digunakan untuk mengukur kemampuan mengajar dosen, motivasi mengajar dosen, dan layanan pendidikan dosen kepada mahasiswa, ditunjukkan pada tabel berikut:

Tabel 3

Kisi-Kisi Instrumen Penelitian

(Adaptasi Sri Budi Rahayu 2004)

a. Kisi-kisi untuk kemampuan (X1)

\begin{tabular}{|c|c|c|c|}
\hline VARIABEL & DIMENSI & INDIKATOR-INDIKATOR & NO. ITEM \\
\hline 1 & 2 & 3 & 4 \\
\hline $\begin{array}{c}\text { Kemampuan } \\
\text { Dosen }\end{array}$ & Keterampilan & \begin{tabular}{|ll} 
a. & Kelincahan mental-berpikir dari \\
& segala arah \\
b. & Kelincahan mental-berpikirke \\
& segala arah \\
c. & Fleksibel konsep \\
d. & Latar belakangyang merangsang \\
e. & Kecakapan \\
f. & Bekerja keras \\
g. & Pantang menyerah \\
h. & Mampu berkomunikasi. \\
i. & Rasa ingin tahu tentang \\
j. & pengetahuan. \\
j. & gerbuka \& menerima informasi / \\
k. & Arah hidupnya mantap dan mandiri \\
a. & Menjalankan Tugas \\
b. & Mengadakan Variasi
\end{tabular} & $\begin{array}{c}2 \\
3 \\
4 \\
5 \\
6 \\
7 \\
8 \\
9 \\
10-11 \\
\\
12 \\
13-17 \\
18-20 \\
\end{array}$ \\
\hline
\end{tabular}

b. Kisi-kisi untuk Motivasi mengajar dosen (X2).

\begin{tabular}{|c|c|c|c|}
\hline VARIABEL & DIMENSI & INDIKATOR-INDIKATOR & NO. ITEM \\
\hline 1 & 2 & 3 & 4 \\
\hline Motivasi & \multirow{7}{*}{ Motif } & a. Kebutuhan ekonomis & 1 \\
\hline Mengajar & & b. Rasa aman dalam bekerja & 2 \\
\hline \multirow{5}{*}{$\begin{array}{l}\text { Dosen } \\
\left(\mathrm{X}_{2}\right)\end{array}$} & & c. Kepuasan dalam melaksanakan & 3 \\
\hline & & $\begin{array}{l}\text { d. Mengembangkan diriuntuk berka- } \\
\text { reirdan memperolehkemajuan }\end{array}$ & 4 \\
\hline & & e. Rasa ingin tahu pekerjaan & 5 \\
\hline & & f. Menggunakan cara-carabaru & 6 \\
\hline & & $\begin{array}{l}\text { g. Melaksanakan suatu pekerjaan } \\
\text { dengan rekan-rekan }\end{array}$ & $7-8$ \\
\hline
\end{tabular}




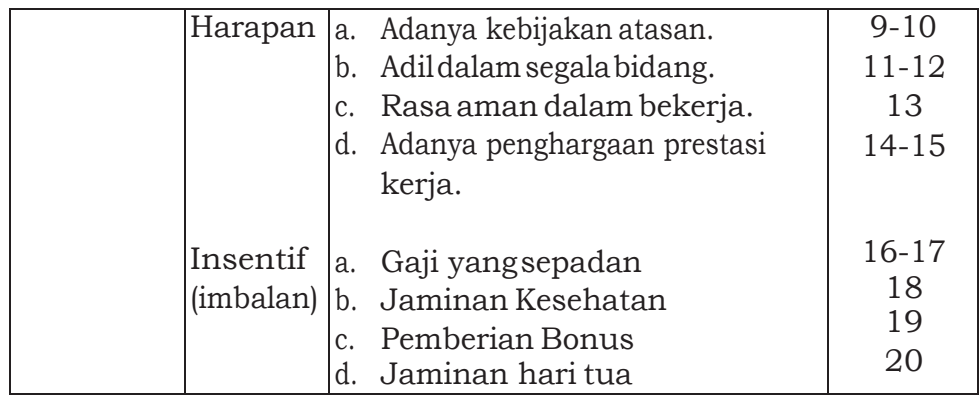

c. Kisi-kisi untuk layanan pendidikan dosen kepada mahasiswa $(\mathrm{Y})$ :

\begin{tabular}{|c|c|c|c|}
\hline VARIABEL & DIMENSI & INDIKATOR-INDIKATOR & NO. ITEM \\
\hline 1 & 2 & 3 & 4 \\
\hline \multirow{20}{*}{$\begin{array}{l}\text { Kualitas } \\
\text { Layanan } \\
\text { Pendidikan } \\
\text { (Y) }\end{array}$} & \multirow[t]{2}{*}{ Tangibles } & a. Peralatan & 1 \\
\hline & & b. Perlengkapan & 2 \\
\hline & \multirow[t]{2}{*}{ Reliability } & a. Kecepatan proses pelayanan & 3 \\
\hline & & b. Adil dalam pelayanan & 4 \\
\hline & \multirow[t]{2}{*}{ Responsivness } & a. Mampu menjalankan tugas & 5 \\
\hline & & b. Terampil dalam pekerjaan & 6 \\
\hline & \multirow[t]{2}{*}{ Competence } & a. Mampu menjalankan tugas & 7 \\
\hline & & b. Terampilterhadap pekerjaan & 8 \\
\hline & \multirow[t]{2}{*}{ Courtesy } & a. Ramah dan bersahabat & 9 \\
\hline & & $\begin{array}{l}\text { b. Tanggap keinginan } \\
\text { mahasiswa }\end{array}$ & 10 \\
\hline & \multirow[t]{2}{*}{ Credibility } & a. Jujur dalam tindakan & 11 \\
\hline & & $\begin{array}{l}\text { b. Amanah dalam menjalankan } \\
\text { tugas }\end{array}$ & 12 \\
\hline & \multirow[t]{2}{*}{ Security } & a. Jaminan pelayanan & 13 \\
\hline & & b. Kepastian Hukum & 14 \\
\hline & \multirow[t]{2}{*}{ Acces } & $\begin{array}{l}\text { a. Mudah untuk mengadakan } \\
\text { kontak }\end{array}$ & 15 \\
\hline & & $\begin{array}{l}\text { b. Pendekatan yanghumanis } \\
\text { dengan mahasiswa }\end{array}$ & 16 \\
\hline & \multirow{4}{*}{$\begin{array}{l}\text { Comunications } \\
\text { Undertsanding } \\
\text { the Student }\end{array}$} & a. Mampu berkomunikasi & 17 \\
\hline & & b. Memberi informasi baru & 18 \\
\hline & & $\begin{array}{l}\text { a. Tahuapayangdibutuhkan } \\
\text { mahasiswa }\end{array}$ & 19 \\
\hline & & $\begin{array}{l}\text { b. Memberikan pelayanan } \\
\text { sesuai dengan selera } \\
\text { mahasiswa }\end{array}$ & 20 \\
\hline
\end{tabular}




\section{Teknik Analisis Data}

Untuk melakukan analisis data, penelitian ini menggunakan bantuan teknik analisis statistik. Teknik statistik regresi ini digunakan untuk menguji hipotesis yang sudah diajukan pada bagian terdahulu. Statistik yang digunakan adalah statistik regresi sederhana; regresi ganda; korelasi sederhana dan korelasi ganda.

\section{HASIL PENELITIAN DAN PEMBAHASAN}

Hasil deskriptif data responden variabel yakni Kemampuan $\left(\mathrm{X}_{1}\right)$, Motivasi mengajar $\left(\mathrm{X}_{2}\right)$, dan Kualitas Layanan Mahasiswa $(\mathrm{Y})$ di STAI Darul Ulum Banyuwangi digambarkan bahwa :

1. Kemampuan Mengajar $\left(\mathrm{X}_{1}\right)$ terdapat jumlah kasus 64 orang yang mengisi angket. Diperoleh hasil untuk: rata-rata (mean) sebesar 49,95; titik tengah (median) $=46,5$; nilai yang sering muncul $($ mode $)=46 ;$ simpangan baku $($ standar deviasi $)=10.06$; tingkat penyebaran data $($ variance $)=101.19$; rentangan $($ range $)=45$; skor minimum dari data $=27$ dan skor maksimum dari data $=$ 72. Sedangkan jumlah skor keseluruhan sebesar 3197.

2. Motivasi mengajar $\left(\mathrm{X}_{2}\right)$ terdapat jumlah kasus 64 orang yang mengisi angket. Diperoleh hasil untuk: rata-rata (mean) sebesar 49,94; titik tengah $($ median $)=51 ;$ nilai yang sering muncul ( mode $)=64 ;$ simpangar baku (standar deviasi) $=10,06$; tingkat penyebaran data $($ variance $)=101,11$; rentangan $($ range $)=47$; skor minimum dari data $=26$ dan skor maksimum dari data $=$ 73. Sedangkan jumlah skor keseluruhan sebesar 3196.

3. Layanan kepada Mahasiswa (Y) terdapat jumlah kasus 64 orang yang mengisi angket. Diperoleh hasil untuk: rata-rata (mean) sebesar 50,02: titik tengah (median) $=51$; nilai yang sering muncul $($ mode $)=53$; simpangan baku ( standar deviasi) $=10$; tingkat penyebaran data $($ variance $)=99,98$; rentangan $($ range $)=$ 50 ; skor minimum dari data $=22$ dan skor maksimum dari data $=72$. Sedangkan jumlah skor keseluruhan sebesar 3201 . 


\section{Analisis Data}

Langkah pertama analisis data adalah melakukan serangkaian pengujian terhadap hipotesis dengan mengunakan teknik analisis statistik yang sudah ditentukan semula, yaitu analisis korelasi, regresi baik sederhana maupun berganda diuraikan sebagai berikut. Berdasarkan perhitungan dari program Microsoft Excel, menggunakan data yang sudah dibakukan (dinaikkan dari data ordinal menjadi data interval) diperoleh hasil sebagai berikut :

Tabel 12. Ringkasan Hasil Perhitungan Dengan Ms. Excel

\begin{tabular}{|c|c|c|c|c|c|c|c|c|}
\hline$\Sigma \mathrm{X}_{1}$ & $\Sigma \mathrm{X}_{2}$ & $\Sigma \mathrm{Y}$ & $\Sigma \mathrm{X}_{12}$ & $\Sigma \mathrm{X}_{12}$ & $\Sigma \mathrm{Y}$ & $\Sigma \mathrm{X}_{1} \mathrm{Y}$ & $\Sigma \mathrm{X}_{2} \mathrm{Y}$ & $\Sigma \mathrm{X}_{1} \mathrm{X}_{2}$ \\
\hline 3197 & 3196 & 3201 & 166075 & 165970 & 166399 & 164122 & 163910 & 164055 \\
\hline
\end{tabular}

a. Analisis Korelasi untuk X, dengan Y.

Pengaruh antara variabel kemampuan $\left(\mathrm{X}_{1}\right)$ dengan layanan mahasiswa ( $Y$ ) sebesar $r_{x 1 y}=0,666$ tergolong tinggi (kuat). Sedangkan untuk menyatakan besar kecilnya kontribusi (sumbangan) variabel $\mathrm{X}_{1}$, terhadap Yatau koefisien diterminan $=r^{2} \times 100 \%$ atau $0,6662 \times 100 \%=44,36 \%$ sedangkan sisanya $55,64 \%$ ditentukan oleh variabel lain.

b. Analisis Korelasi untuk X2 dengan Y

Pengaruh antara variabel motivasi mengajar $\left(\mathrm{X}_{2}\right)$ dengan kualitas layanan kepada mahasiswa (Y) sebesar $\mathrm{r}_{\mathrm{X} 2 \mathrm{Y}}=0,641$ tergolong tinggi (kuat). Sedangkanuntuk menyatakan besar kecilnya kontribusi variabel $\mathrm{X}_{2}$, terhadap $\mathrm{Y}$ atau koefisien diterminan $=r^{2} \times 100 \%$ atau $0,6412 \times 100 \%=41,09 \%$ sedangkan sisanya $58,91 \%$ ditentukan oleh variabellain.

c. Analisis Korelasi untuk X1 dengan X2

Hubungan antara variabel kemampuan mengajar dosen $\left(\mathrm{X}_{1}\right)$ dengan motivasi mengajar $\left(\mathrm{X}_{2}\right)$ sebesar $\mathrm{r}_{\mathrm{x} 1 \mathrm{x} 2}=0,691$ tergolong tinggi (kuat). Sedangkan untuk menyatakan besar kecilnya kontribusi variabel $\mathrm{X}_{1}$ terhadap $\mathrm{X}_{2}$ atau koefisien 
diterminan $=r^{2} \times 100 \%$ atau $0,6912 \times 100 \%=47,75 \%$ sedangkan sisanya $52,25 \%$ ditentukan oleh variabel lain.

d. Analisis Korelasi Ganda untuk X1 dan X2 dengan Y

Pengaruh secara simultan antara variabel kemampuan $\left(\mathrm{X}_{1}\right)$ dan motivasi mengajar $\left(\mathrm{X}_{2}\right)$ terhadap kualitas layanan kepada mahasiswa (Y) sebesar 0,712 tergolong kuat. Sedangkan kontribusi secara bersama-sama (simultan) variabel $\mathrm{X}_{1}$ dan $\mathrm{X}_{2}$ terhadap $(\mathrm{Y})=\mathrm{R}^{2} \mathrm{x} 100 \%=50,6 \%$ sedangkan sisanya 49,4 $\%$ ditentukan oleh variabel lain.

\section{Pengujian Hipotesis}

Setelahmendeskripsikanhasilpenelitian, langkahselanjutnya adalah melakukan interpretasi hasil analisis penelitian yaitu melakukan penafsiran terhadap pengujian hipotesis. Walaupun hasil analisis statistik itu sendiri sudah merupakan suatu kesimpulan, tetapi belum memadai tanpa ada interpretasi yang dikaitkan dengan rumusan masalah. Interpretasi dan pengujian hipotesis diuraikan sebagai berikut:

a. Ada pengaruh yang signifikan antara kemampuan dosen terhadap kualitas layanan kepada mahasiswa.

Berdasarkan Tabel 11 bahwa besarnya pengaruh antara variabel kemampuan $\left(\mathrm{X}_{1}\right)$ terhadap kualitas layanan kepada mahasiswa $(\mathrm{Y})$ yang dihitung dengan koefisien korelasi adalah 0,666 atau $\left(\mathrm{r}_{\mathrm{X} 1 \mathrm{Y}}=\mathrm{O}, 666\right)$. Hal ini menunjukkan pengaruh yang kuat antara kemampuan dosen terhadap kualitas layanan kepada mahasiswa. Sedangkan tingkat signifikan koefisien korelasi satu sisi (1-tailed) dari output (diukur dari probabilitas) menghasilkan angka 0,00 atau 0. Karena probabilitas jauh di bawah 0,01 atau 0,05, maka pengaruh antara kemampuan dosen terhadap kualitas pelayanan kepada mahasiswa signifikan.

b. Ada pengaruh yang signifiikan antara motivasi mengajar dosen terhadapkualitas layanan kepada mahasiswa. 
Berdasarkan Tabel 11, bahwa besarnya pengaruh antara variabel motivasi mengajar dosen $\left(\mathrm{X}_{2}\right)$ terhadap kualitas layanankepadamahasiswa $(\mathrm{Y})$ yangdihitungdengankoefisien korelasi adalah 0,641 atau $\left(\mathrm{r}_{\mathrm{X} 2 \mathrm{Y}}=0,641\right)$. Hal ini menunjukkan pengaruh, yang kuat di antara motivasi mengajar dosen terhadap kualitas layanan kepada mahasiswa. Sedangkan tingkat signifikan koefisien korelasi satu sisi (1-tailed) dari output (diukur dari probabilitas) menghasilkan angka 0,00 atau 0 . Karena probabilitas jauh di bawah 0,01 atau 0,05, maka pengaruh antara motivasi mengajar dosen terhadap kualitas layanan kepada mahasiswa signifikan.

c. Ada hubungan yang signifikan antara kemampuan dengan motivasi mengajardosen.

Berdasarkan Tabel 11 bahwa besarnya hubungan antara variabel kemampuan $\left(\mathrm{X}_{2}\right)$ dengan motivasi mengajar dosen $\left(\mathrm{X}_{2}\right)$ yang dihitung dengan koefisien, korelasi adalah 0,691 atau $\left(r_{\mathrm{X} 1 Y 2}=0,691\right)$. Hal ini menunjukkan pengaruh yang kuat di antara variabel kemampuan dengan motivasi mengajar dosen. Sedangkan tingkat signifikan koefisien korelasi satu sisi (1-tailed) dan output (diukur dari probabilitas) menghasilkan angka 0,000. Karena prababilitas jauh di bawah 0,05 maka korelasi antara variabel kemampuan dengan motivasi mengajar dosen adalah signifikan.

d. Ada pengaruh yang signifikan antara kemampuan dan motivasi mengajar dosen secara simultan terhadap kualitas layanan kepada mahasiswa.

Berdasarkan analisis Tabel 12 terdapat $\mathrm{R}$ square adalah 0,506 (adalah pengkuadratan dari koefisien korelasi 0,712 atau 0,7122$)$. $\mathrm{R}$ square dapat disebut koefisien diterminasi yang dalam hal ini berarti 50,6\% kontribusi variabel kemampuan dan motivasi mengajar terhadap kualitas layanan kepada mahasiswa sedangkan sisanya 49,4\% dapat dijelaskan oleh sebab-sebab yang lain. $\mathrm{R}$ square berkisar pada angka 0 sampai 1, dengan catatan semakin kecil angka 
R square, semakin lemah pula hubungan kedua atau lebih variabel tersebut. Jadi, kemampuan dan motivasi mengajar dosen secara simultan terhadap kualitas layanan kepada mahasiswa kotribusinya sebesar 50,6\%.

\section{E. KESIMPULAN}

Penelitian ini menunjukan besarnya pengaruh secara simultan antara variabel kemampuan dosen $\left(\mathrm{X}_{1}\right)$ dan motivasimengajar $\left(\mathrm{X}_{2}\right)$ terhadap kualitas pelayanan kepada mahasiswa (Y) tergolong kuat. Sedangkan kontribusi secara bersama-sama (simultan) variabel $\mathrm{X}_{1}$, dan $\mathrm{X}_{2}$ terhadap $(\mathrm{Y})=\mathrm{R}^{2} \mathrm{x} 100 \%$ atau $0,7122 \times 100 \%=50,6 \%$ sedangkan sisanya 49,4\% ditentukan oleh variabel lain. Kemudian mengenai naik turunnya atau besar kecilnya kualitas layanan kepada mahasiswa dapat diprediksi melalui persamaan regresi $\mathrm{Y}=$ $11,633+0,427 \mathrm{X}_{1}+0,345 \mathrm{X}_{2}$ sehingga dari hasil penelitian inidapat ditarik beberapa sub kesimpulan sebagai berikut:

1. Kemampuan dosen berpengaruh secara signifikan terhadap kualitas layanan kepada mahasiswa.

Besarnya pengaruh variabel kemampuan dosen terhadap kualitas layanan kepada mahasiswa adalah 0,666 sedangkan konstribusi variabel $\mathrm{X}_{1}$ terhadap $\mathrm{Y}$ sebesar 44,36 \% kemudian sisanya 55,64\% ditentukan oleh variabel lain. Infomasi ini memberikan keterangan bahwa variabel kemampuan dosen memberikan pengaruh kuat terhadap kualitas layanan kepada mahasiswa. Hasil penelitian ini menginformasikan bahwa Kemampuan yang dimiliki oleh dosen dan penerapan mahasiswa pada mahasiswa dalam tingkat atau kategori baik dan akan lebih mewujudkan kinerja yang optimal sehingga diharapkan akan mempengaruhi efektifitas kerja maupun kualitas layanan kepada mahasiswa yang diberikan kepada mahasiswa dengan pelayanan yang ramah, santun dan profesional.

2. Motivasi mengajar dosen berpengaruh secara signifikan terhadap kualitas layanan kepada mahasiswa. 
Besarnya pengaruh variabel motivasi mengajar dosen terhadap kualitas layanan kepada mahasiswa adalah 0,641 adapun konstribusi variabel $\mathrm{X}_{2}$ terhadap $\mathrm{Y}$ sebesar $41,09 \%$ kemudian sisanya 58,91\% ditentukan oleh variabel lain. Informasi ini memberikan keterangan bahwa variabel motivasi mengajar dosen memberikan pengaruh kuat terhadap kualitas layanan kepada mahasiswa.

Temuan penelitian ini menerangkan bahwa pemberian dan penerapan motivasi mengajar yang diberikan oleh pimpinan perguruan tinggi kepada dosen selama ini menunjukkan tingkat yang cukup baik dan mencerminkan tingkat kualitas pelayanan yang baik pula, pemberian motivasi baik dari pimpinan maupun dari dalam diri dosen diharapkan akan mempengaruhi produktivitas mengajar yangoptimal dan mampu memberikan layanan pembelajaran kepada mahasiswa yang ramah, simpatik dan memuaskan.

3. Kemampuan dosen berhubungan dengan motivasi mengajar

Besarnya hubungan kemampuan dosen dengan motivasi mengajar adalah 0,691 kemudian konstribusi variabel $\mathrm{X}_{1}$ dengan $\mathrm{X}_{2}$ sebesar $47,75 \%$ sedangkan sisanya $52,25 \%$ ditentukan oleh variabel lain. Temuan penelitian ini menginformasikan bahwa kemampuan dosen mempunyai kaitan yang positif terhadap motivasi mengajarnya. Dengan demikian kemampuan dosen akan membentuk profesionalisasi dosen yang menunjukkan suatu tindakan pekerjaan yang berdampak positif bagi kinerja dosen dan perkembangan pribadinya.

Bentuk tindakan tersebut dapat berwujud kecakapan dan terampil melayani mahasiswa di perguruan tinggi. Pemberian motivasi oleh pimpinan yang disertai dengan kemampuan dosen yang berkualitas akan sangat mempengaruhi kinerja dosen secara optimal. Kemampuan dosen akan mempengaruhi motivasi mengajar dalam menangani pelayanan kepada yang membutuhkan layanannya.[] 


\section{DAFTAR PUSTAKA}

Somad, Abdul, "Analisis Faktor yang Berhubungan dengan Kompetensi Mengajar Dosen Mata Kuliah Kebidanan di Akademi Kebidanan Depkes Jambi," (Tahun 2001) diakses dari http: / / www. digilib. ui.ac.id/opac/themes/libri2/ detail. jsp?id=72297.

Lestari, Anita Tri,"Hubungan Kualitas Layanan Registrasi Akademik dengan Tingkat Kepuasan Mahasiswa di Perguruan tinggi Tinggi Keguruan Ilmu Pendidikan (STKIP) PGRI Pasuruan," Skripsi, tidak diterbitkan, Malang: Universitas NegeriMalang, 2010.

Arikunto, Suharsimi, Prosedur Penelitian Suatu Pendekatan Praktek, Yogyakarta: Rineka Cipta, 1998, Cet. Ke-8,

Benyamin, S. Bloom. Et.all. Evaluation to Improve Learning. New York: Mc Graw-Hill Book Company, 1981.

Bob Davis. Et.al, Physical Education and The Study of Sport, Second Edition, Mosby: Times Mirror International Publisher Limited, 1994.

E. Mulyasa, Menjadi Dosen Profesional, Jakarta: Remaja Rosda Karya, 2005.

Eko Nugroho, "Pengaruh Persepsi Mahasiswa Mengenai Kemampuan Dosen Dalam Proses Perkuliahan Dan Motivasi Belajar Terhadap Prestasi Belajar Pada Mahasiswa PPKn Universitas Muhammadiyah Surakarta Tahun Akademik 2006/2007," Skripsi. Surakarta: Universitas Muhammadiyah Surakarta, 2007.

Gaspersz. Vincent, Manajemen Kualitas; Penerapan Konsep-Konsep Kualitas dalam Manajemen Bisnis Total, Jakarta: Gramedia Pustaka Utama, 1997 
Hendrik Isu, "Unsur Kreatifitas dalam Supervisi Pengajaran dan Pengembangan Situasi Belajar Mengajar," Tesis, Bandung: FSP IKIP, 1996.

Lovelock, Christoper, H, Managing Services: Marketing, Operations and Human Resources, New Jersey: Prentice Hall Englewood Cliffs, 1992

Mangunhardjana, A. M., Mengembangkan Kreativitas, (terj. Dari David Cambell), Jakarta: Kanisius, 1986.

Masri Singarimbun, Metode Penelitian Survai, Jakarta: Rajawali, 1987

Parasuraman, A., Dilivering Quality Service. Balancing Customer PerceptionsandExpectations. NewYork:TheFreePress, 1994.

Piers,E.V. "Creativity" dalam J.F. Adam (Ed.), Undertanding Adolescence: Current Developments in Adolescence Psychology, Boston: Allyn \& Bacon, 1976.

R. Terry, George, Prinsip-Prinsip Manajemen, Bumi Aksara. Jakarta. Riduwan, Metode dan Teknik Menyusun Tesis, Bandung: CV.Alfabeta, 2004

Robbins, Stephen P, Perilaku Organisasi, (Terjemahan), Jakarta: Indeks Kelompok Gramedia, 2006.

Sahlan, Sulaiman, Multi Dimensi Sumber Kreativitas Manusia, Bandung: Sinar Baru, 1988.

Sedarmayanti. Sumberdaya Manusia dan Produktivitas Kerja, Bandung: Ilham Jaya, 2001.

Semiawan, Conny, Memupuk Bakat dan Kreativitas Mahasiswa Perguruan Tinggi, Jakarta: Gramedia, 1984

Sumarsono, Sonny, Metode Riset Sumber Daya Manusia, Jakarta: Graha Ilmu, 2004.

Rahayu, Sri Budi, Pengaruh Kemampuan dan Motivasimengajar Perawat Terhadap Kualitas Pelayanan Kesehatan Pada Rumah Sakit Santo Boromoeous Bandung, Bandung: Universitas Pendidikan Indonesia, 2004. 
Kusumadewi, Sri, "Fuzzy Quantification Theory Untuk Analisis Hubungan Antara Penilaian Kinerja Dosen Oleh Mahasiswa, Kehadiran Dosen, Dan Nilai Kelulusan Mahasiswa," Jurnal Media Informatika, Vol. 2, No. 1, Juni 2004, 1-1.

Sulastri, Sri, Pengaruh Kepemimpinan dan Motivasi mengajar Terhadap Prestasi Kerja Dosen (PPS), Bandung: Universitas Pajajaran, 2002.

Widayati, Sri, dkk., Reformasi Pendidikan Dasar. Diterbitkan atas Kerjasama Universitas Katholik Atma Jaya Jakarta, Jakarta: Penerbit Grasindo, 2002.

Sudarmanto, YB., Tuntunan Metodologi Belajar, Jakarta: Kerjasama Univeritas Katolik Soegijapranata Semarang dan Gramedia Widiasarana Indonesia, 1995

Sudjana, Endang, "Hubungan Kepuasan Kerja dengan Kreativitas

Dosen dalam Proses Belajar Mengajar," Tesis, Program Pasca Sarjana Universitas Pendidikan Indonesia. Bandung, 2000

Sugiyono, Metode Penelitian Administrasi, Bandung: Alfabetha, 2002.

Suharto, Nugraha, "Pelaksanaan Penilaian Jabatan Fungsional Dosen dan Pengaruhnya terhadap Kualitas Kinerja Dosen Perguruan Tinggi," Tesis Program Pasca Sarjana Universitas Pendidikan Indonesia, Bandung, 2000.

Sulistyowati. "Pengaruh Persepsi Dosen tentang Keterampilan Kepemimpinan Kepala Perguruan tinggi terhadap Kualitas Layanan (Studi pada Dosen SMAN 1 Blitar)," Skripsi, Program Studi Pendidikan Akuntansi, Jurusan Akuntansi, Fakultas Ekonomi, Universitas Negeri Malang. 2009.

Supriadi, Dedi, Kreativitas Kebudayaan dan Perkembangan Iptek, Bandung: Alfabeta,2006.

Supriyanto, "Pengaruh Gaya Kepemimpinan Kyai, Profesionalisme Pengurus dan Kontribusi Alumni dalam Pemberdayaan Koperasi Pondok Pesantren," Jakarta: Kementrian Agama RI, 2010. 
Supriyanto, "Pengembangan Perekonomian Pesantren dalam Perspektif Pendidikan Ekonomi: Studi Multi Situs di PP Pasuruan dan PP Minhajut Thullab Banyuwangi," Disertasi, tidak Diterbitkan, Malang: Universitas Negeri Malang, 2010

Supriyanto. "Pengaruh Motivasi dan Kemampuan Guru Terhadap

Penerapan Pembelajaran Kontekstual pada Guru IPS SMA

Kabupaten Banyuwangi” Tesis, tidak diterbitkan, Malang: Universitas Kanjuruhan Malang, 2006.

Suradinata, Ermaya, Lembaga Pendidikan Tinggi dan Manajemen Pemerintahan, Bandung: Romadan, 1996.

Surakhmad, Winarno, Pengantar Penelitian Ilmiah, Bandung: Tarsito, 1994

Susanti, Ida dan Seto Bayu, "Aspek Hukum dari Perdagangan Bebas: Menelaah Kesiapan Hukum Indonesia dalam Melaksanakan Perdagangan Bebas," Bandung: Fakultas Hukum Universitas Katolik Parahyangan, 2003.

Sutaryadi (ed), Administrasi Pendidikan: Teori, Riset dan Praktis, Surabaya: Usaha Nasional, 1993.

Sutermeister. R.A. People and Productivity (Third Edition), New York: Mc. Grow Hill Book Company, 1976.

Syarif, Rusli, Produktivitas, Bandung: Angkasa, 1991.

The QS Words University Rangkings. Quacquarelly Symonds. 2009. Publikasi oleh http: www. ruanghati. com. Desember. 2010. Dapat diakses juga di http://i684. photobucket. com/albums /vv210/mesinkasir/metode.png.

Tim Penyusun, Kamus Besar Bahasa Indonesia, Jakarta: Departemen Pendidikan Nasional Republik Indonesia, 1996.

Tommy Joesoef, Pengaruh Kinerja Dosen Terhadap Kualitas Pelayanan Kesehatan di Rumah Sakit Dustira Cimahi, Bandung: Universitas Pajajaran, 2001.

Tri Kurniawati, "Pengujian tentang Pengaruh Kualitas Layanan Akademik terhadap Prestasi Belajar Mahasiswa di Prodi 
Pendidikan Ekonomi Universitas Negeri Padang dengan MotivasiBelajar sebagai Intervening Variable,"Tesis, Malang: Program Pasca Sarjana Universitas Negeri Malang, 2010.

Trisno Hadi Subroto, Pengajaran Reflektif, Surabaya: Kerjasama SIC Surabaya dan LPM IKIP Surabaya, 2004

Usman, Moh. Uzer, Menjadi Dosen Profesional, Bandung: Remaja Rosdakarya, 1992.

Widayat, Metode Penelitian Pemasaran; Aplikasi Sofware SPSS, Malang: UMM Press, 2004.

Zaini Hasan, H.M., "Statistika, Kumpulan Materi 1," Bahan Perkuliahan Program Pasca Sarjana Universitas Kanjuruhan Malang, 2005

Zethami Valirie. A. Parasuraman A. Leonard L. Berry, Delivering Quality Service. Balancing Customer Perceptions and Expectations, New York: The Free Press, 1990. 